\title{
ANALISIS PENGARUH PRODUK BARU TERHADAP KEPUTUSAN UNTUK MEMBELI PADA PT. DONINDO MENARA UTAMA BANJARMASIN
}

\author{
Susiladewi \\ dewi.susila@gmail.com \\ Basuki \\ msibasukidr@gmail.com \\ Universitas Islam Kalimantan MAB Banjarmasin
}

\begin{abstract}
Increasing population and increasing people's income in Banjarmasin city will increase people's need for comfortable house either as a residence as an investment in the future.

The purpose of this study is to know and analyze about new products produced by PT.Donindo Menara Utama Company in relation to the buying decision of the Consumers inhabiting the complex of Metro Indah Housing Banjarmasin.

This research is done by taking the object of research that is in Metro Indah Housing Complex which is located at Brig Jend H. Hasan Basri Kayu Tangi Banjarmasin

Sample amounted to 32 people, taken 10\% of the total population of 110 people. Relationship analysis using product moment correlation coefficient sought by the formula of coarse numbers or also called Raw Score method.

The result of the research is the coefficient between the new product variables and the decision variable to buy the housing complex of Metro Indah housing owned by PT.Doninda Menara Utama Banjarmasin which is 0.577. The $r$ table for $N$ of 30 with a significant level of $5 \%$ is 0.361 . The coefficient of correlation of new Product variable with decision variable to buy is greater than correlation value listed in table of product moment $r$ value. It can be concluded that the correlation coefficient of both variables studied is significant or positive.
\end{abstract}

Keywords: New product; Decision to buy

\section{PENDAHULUAN}

Rumah pada intinya memiliki fungsi yang begitu banyak misalnya selain fungsinya sebagai tempat tinggal, rumah juga bisa dijadikan sebagai suatu Investasi dan dapat dijadikan sebagai salah satu sumber pendapatan bagi keluarga, misalnya 
orang membeli rumah dengan Banjarmasin juga tergolong tinggi tujuan untuk disewakan atau dan bahkan terus mengalami dikontrakan atau bahkan mungkin peningkatan.

dijadikan sebagai tempat berusaha dan lain sebagainya.

Banjarmasin sebagai ibukota Provinsi Kalimantan Selatan yang merupakan salah satu kota besar di lndonesia dan bahkan satu-satunya kota besar di Kalimanan Selatan yang memiliki jumlah penduduk paling padat diwilayah Kalimantan Selatan.

Jumlah penduduk kota Banjarmasin tahun 2004 sebanyak 572.300 Orang dengan tingkat pertumbuhan $1,10 \%$, pada tahun 2005 jumlah penduduk kota Banjarmasin Tahun 2005 ada sebanyak 589.115 dengan tingkat pertumbuhan 2,04\%, dan terakhir tahun 2006 jumlah penduduk kota Banjarmasin terdapat 602.725 Orang dengan tingkat pertumbuhan 2,08\%.

Selain jumlah penduduk yang tergolong besar Indeks Pembangunan Manusia Kota

Melihat kondisi semacam ini maka wajarlah kalau PT.Donindo Menara Utama Pada tahun 2002 yang telah lalu mencoba melakukan strategi pengembangan produk yaitu menghasilkan produk baru berupa bangunan rumah dikomplek perumahan Metro Indah Banjarmasin, rumah yang dibangun oleh PT.Donindo menara Utama tergolong rumah mewah.

Basu Swasta dan Irwan ( 2003;

53) Remarketing atau peningkatan penjualan dapat dilakukan bilamana masih terdapat kemungkinan untuk memperbaharui produk atau jasa yang semakin menurun tersebut. Disini menejer pemasaran berusaha mencari usul-usul baru dalam penawarannya pada pasar potensial.

Produk yang dipilih oleh PT.Donindo Menara Utama adalah membangun perumahan menengah keatas tentunya dengan berbagai 
pertimbangan diantaranya Pangsa pasar Perumahan Menengah keatas dikota Banjarmasin cukup besar, Pengembang yang melayani Pangsa Pasar menengah keatas masih sangat relatif sedikit karena untuk membangun perumahan menengah keatas memerlukan modal yang besar selain itu membangun perumahan juga tidak jauh berbeda dengan usaha sebelumnya yang digeluti oleh PT.Donindo Menara Utama.

Tujuan penelitian ini adalah untuk mengetahui dan menganalisis tentang produk baru yang dihasilkan oleh Perusahaan PT.Donindo Menara Utama dalam kaitannya keputusan membeli dari Konsumen yang mendiami komplek Perumahan Metro Indah Banjarmasin.

\section{TINJAUAN PUSTAKA}

\section{1) Pengembangan Produk}

Pengembangan Produk tiada lain adalah produk baru yang dihasilkan oleh suatu perusahaan guna untuk menyikap terjadinya pergeseran atau perobahan selera konsumen.

\section{2) Pengertian Produk Baru}

Pengembangan produk tiada lain adalah produk baru yang dihasilkan oleh suatu perusahaan yang berbeda dengan produk sebelumya baik itu dari jenis, bentuk dan lain sebagainya.

Prilaku konsumen dapat dinyatakan sebagai sebuah proses teratur oteh orang-orang dalam merencanakan, membeli dan menggunakan barang-barang ekonomi dan jasa. Untuk memahami proses mendasari dan mengarahkan konsumen dalam melakukan pembelian, ada beberapa teori perilaku konsumen yaitu : (1) Teori ekonomi mikro, (2) Teori psikologis, (3) teori sosiologis dan (4) teori antropologis, (Swastha, 1997).

Teori ekonomi mikro menyatakan bahwa keputusan untuk membeli merupakan hasil dari perhitungan ekonomis secara rasional dan sadar. Pembeli 
(individu) berusaha menggunakan barang-barang yang akan memberikan kegunaan (Kepuasan) yang paling banyak, sesuai dengan selera dan harga-harga relatif.

\section{3) Hubungan antara Prilaku} Konsumen dengan Strategi

\section{Pemasaran}

Keadaan diluar perusahaan yang harus diamati pertamakali adalah tentang prilaku konsumen, ini karena prilaku konsumen mempunyai implikasi yang luas terhadap pemasaran. Oleh karena itu perumusan strategi pemasaran merupakan suatu rencana yang diutamakan untuk mencapai tujuan perusahaan.

Tujuan perusahaan adalah memperoleh keuntungan melalui keputusan konsumen dan masyarakat. Menurut Kotler (1996) strategi pemasaran menyangkut dua kegiatan pokok yaitu :

(1) Pemilihan Pasar

Sasaran yang dijadikan sebagai sasaran pemasaran (target market) yaitu : suatu kegiatan yang memerlukan kemampuan untuk memahami prilaku konsumen dan mengukur secara efektif kesempatan pemasaran diberbagai segmen pasar. (2) Merumuskan dan menyusun kombinasi

Perumusan dan penyusunan suatu kombinasi yang tepat dari marketing mix agar kebutuhan konsumen dapat dipenuhi secara memuaskan.

Untuk menilai kebutuhan diberbagai segemen pasar yang berlainan dan prilaku konsumen dalam memberikan tanggapan terhadap kegiatan pemasaran perusahaan, merupakan kegiatan yang memerlukan kemampuan.

Salah satu contoh besarnya pengaruh prilku konsumen terhadap perumusan strategi pemasaran ialah bahwa perubahan prilaku konsumen sekarang tidak memperhatikan harga saja dalam membelinya, tetapi juga kualitas barang, komunikasi pemasaran, pelayanan yang memuaskan dan penyaluran uang 
intensif menjadi lebih penting, ini berarti perumusan strategi pemasaran harus memberikan yang lebih seimbang dengan memperhatikan lebih banyak unsurunsur bukan harga (non price strategi).

\section{4) Faktor yang mempengaruhi}

\section{Keputusan Pembeli}

Didalam manajemen pemasaran modem menurut Basu Swastha (1990) “Tujuan kegiatan pemasaran adalah mempengaruhi pembeli untuk bersedia membeli barang dan jasa perusahaan".

Hal ini sangat penting bagi manajer pemasaran untuk memahami mengapa dan bagaimana tingkah laku konsumen tersebut. Sehingga perusahaan dapat mengembangkan, menentukan harga, mempromosikan dan mendistribusikan produknya dengan baik, yaitu dengan mempelajari prilaku konsumen, manajer mengetahui kesempatan baru yang berasal dari bahanterpenuhinya. Kemudian mengidentifikasikannya untuk mengadakan segmentasi pasar.

Menurut Husein Umar (2003) terdapat dua faktor utama yang mempengaruhi perilaku konsumen, yaitu faktor sosial budaya yang terdiri atas faktor kebudayaan, budaya khusus, kelas sosial, kelompok sosial dan referensi serta keluarga. Faktor lain adalah faktor fsikologis yang terdiri atas motivasi,persepsi,proses belajar, kepercayaan sikap.

\subsection{Kerangka Konseptual}

Berdasarkan penelitian yang dilakukan dan kajian teoritis pada tinjauan pustaka, penelitian ini menggunakan 3 Variabel bebas atau indevenden dan satu variabel terikat atau devenden. Adapun variabel bebas atau Indevenden yaitu Spesifikasi bangunan,harga, dan lokasi. Sedangkan Variabel terikatnya atau Devenden Variabel yaitu adalah keputusan membeli. 


\section{METODE PENELITIAN}

Penelitian ini adalah penelitian kuantitatif yang menguji pengaruh variabel bebas terhadap variabel terikat.

Penelitian ini dilakukan dengan mengambil obyek penelitian yaitu diPerumahan Komplek Metro Indah yang beralamat dijalan BrigJend $\mathrm{H}$. Hasan Basri Kayu Tangi Banjarmasin Sampel pada penelitian ini berjumlah 32 orang yaitu diambil $10 \%$ dari total Populasi yang jumlahnya sebanyak 110 Orang. Dan sampel ini diambil secara acak atau Sampel Random dari blok A, blok B, blok C, dan blok D. Masing masing blok jumlah sampel yang diambil yaitu sebagai berikut :Blok A sebanyak 5 Orang, Blok B sebanyak 5 Orang, Blok C sebanyak 6 Orang dan Blok D sebanyak 6 Orang.

Data Koefisien korelasi digunakan untuk mengetahui seberapa besarnya keeratan hubungan yang terjadi antara variabel bebas (X) dengan variabel terikat (Y).
Sementara itu (Sutrisno Hadi, 2000 : 294) menyatakan bahwa besarnya keeratan hubungan antara $\mathrm{X}$ dan $\mathrm{Y}$ diperlihatkan oleh korelasi untuk memeriksa hubungan antara dua variabel $X$ dan $Y$, dapat digunakan koefisien korelasi product moment dicari dengan rumus angka kasar atau disebut juga Raw Score method.

\section{PEMBAHASAN DAN HASIL}

\section{PENELITIAN}

\subsection{Karakteristik Responden}

Berdasarkan angket yang diisi oleh 30 orang jumlah responden yang menghuni komplek perumahan Metro Indah adalah bekerja di Lembaga Perbankan dan di sektor swasta baik itu sebagai karyawan perusahaan maupun sebagai pengusaha atau pemilik perusahaan. Berdasarkan data yang diperoleh dilapangan bahwa 11 Orang atau $36,67 \%$ responden status pekerjaannya adalah sebagai pengusaha, 15 Orang atau 50\% responden berstatus sebagai karyawan perusahaan swasta. Dan 4 
Orang atau $13,33 \%$ responden pekerjaannya sebagai karyawan Bank.

Tingkat pendidikan responden adalah terdiri dari $6,67 \%$ lulusan Sekolah Lanjutan Tingkat Atas (SLTA), 13,33\% Lulusan Diploma Tiga (D3), 70\% Lulusan Sarjana (S1), dan 10\% lulusan Pasca Sarjana (S2).

\subsection{Intensitas Produk Baru PT. Donindo Menara Utama \\ Banjarmasin}

Dari data yang disusun pada tabel 13 dapat diketahui tentang keadaan produk baru yang dihasilkan oleh PT. Donindo Menara Utama Banjarmasin. Hal ini dapat diketahui bahwa responden yang memiliki Intensitas yang sangat tinggi atas produk baru yang dihasilkan oleh PT. Donindo Menara Utama adalah kosong dan responden yang memiliki Intensitas yang tinggi atas produk baru yang dihasilkan oleh PT. Donindo Menara Utama ada sebanyak 5 orang atau
17\% sementara Intensitas responden yang berada pada posisi sedang ada sebanyak 25 Orang atau 83\% dan Intensitas responden yang berada pada posisi kurang dan rendah adalah kosong. Sedangkan untuk Skor rata-rata dari variabel produk baru adalah 99,5 : $30=3,3$ dan Skor variabel produk baru yang berada diatas nilai rata-rata berjumlah 11 Orang atau $37 \%$ dari seluruh responden, dan untuk skor dibawah nilai rata-rata adalah 19 Orang atau $63 \%$ dari seluruh frekwensi variabel produk baru.

Dapat dikatakan bahwa lntensitas Produk baru yang dihasilkan oleh PT.Donindo Menara Utama Banjarmasin berada pada posisi negative atau dengan kata lain produk baru yang dihasilkannya belum dapat memenuhi seluruh kriteria yang diinginkan oleh konsumen. 
1.3. Intensitas Keputusan untuk responden yang memiliki intensitas membeli (Y) Pada Produk baru PT.Donindo Menara Utama.

Berdasarkan pada poin 1.2 dan 1.3 yaitu persiapan mencari skor keputusan untuk membeli pada produk baru berupa rumah mewah yang dihasilkan oleh PT.Donindo Menara Utama Banjarmasin, maka intensitas keputusan untuk membeli yaitu sebagai berikut :

Responden yang memiliki intensitas keputusan untuk membeli produk baru yang sangat tinggi adalah kosong, responden yang memiliki Intensitas Keputusan untuk membeli produk baru yang tergolong tinggi ada sebanyak 3 Orang atau $10 \%$ dan responden yang memiliki Intensitas Keputusan untuk membeli produk baru yang masuk dalam katagori yang sedang ada sebanyak 18 Orang atau 60\% \%, sementara Responden yang memiliki intensitas Keputusan untuk membeli yang tergolong kurang ada sebanyak9 Orang atau 30\% dan 
keputusan untuk membeli dari diuraikan dalam Metodologi konsumen rumah mewah dikomplek Penelitian. Berdasarkan dari data perumahan Metro Indah yang telah disusun dapat dibuat Banjarmasin dipergunakan perhitungan koefisien korelasi antara pendekatan metode korelasi produk kedua variabel tersebut yaitu sebagai moment dengan cara menggunakan berikut:

rumus angka kasar sebagaimana

Tabel 1

Hubungan antara Produk Baru (X) dengan Keputusan untuk Membeli (Y) Rumah di Metro Indah Banjarmasin

\begin{tabular}{|c|c|c|c|c|c|}
\hline No. & $\mathbf{x}$ & $\mathbf{y}$ & $\mathbf{x}^{\mathbf{2}}$ & $\mathbf{y}^{\mathbf{2}}$ & $\mathbf{x y}$ \\
\hline$(1)$ & $(2)$ & $(3)$ & $(4)$ & $(5)$ & $(6)$ \\
\hline & & & & & \\
01 & 3,9 & 4,5 & 15,21 & 20,25 & 17,55 \\
02 & 3,7 & 3,9 & 13,69 & 15,21 & 14,43 \\
03 & 3,2 & 4,2 & 10,24 & 17,64 & 13,44 \\
04 & 3,7 & 3,4 & 13,69 & 11,56 & 12,58 \\
05 & 3,4 & 3,0 & 11,56 & 9,00 & 10,20 \\
06 & 3,2 & 2,9 & 10,24 & 84,1 & 9,28 \\
07 & 3,2 & 3,1 & 10,24 & 9,61 & 9,92 \\
08 & 3,2 & 3,3 & 10,24 & 10,89 & 10,56 \\
09 & 3,2 & 3,0 & 10,24 & 9,00 & 9,60 \\
10 & 3,4 & 3,0 & 11,56 & 9,00 & 10,20 \\
11 & 3,8 & 2,9 & 14,44 & 8,41 & 11,02 \\
12 & 3,5 & 3,0 & 12,25 & 9,00 & 10,50 \\
13 & 3,3 & 3,2 & 10,89 & 10,24 & 10,56 \\
14 & 3,6 & 2,6 & 12,96 & 6,76 & 9,36 \\
15 & 3,1 & 2,4 & 9,61 & 5,76 & 7,44 \\
16 & 3,4 & 3,1 & 11,56 & 9,61 & 10,54 \\
17 & 3,5 & 2,7 & 12,25 & 7,29 & 9,46 \\
18 & 3,8 & 2,8 & 14,44 & 7,84 & 10,64 \\
19 & 3,9 & 2,5 & 8,41 & 6,25 & 7,25 \\
20 & 3,0 & 2,3 & 9,00 & 5,29 & 6,90 \\
21 & 3,1 & 3,0 & 9,61 & 9,00 & 9,30 \\
\hline
\end{tabular}




\begin{tabular}{|c|c|c|c|c|c|}
\hline 22 & 3,3 & 2,8 & 10,89 & 7,84 & 9,24 \\
23 & 3,2 & 3,1 & 10,24 & 9,61 & 9,29 \\
24 & 3,9 & 2,8 & 8,41 & 7,84 & 8,12 \\
25 & 3,1 & 2,7 & 9,61 & 7,29 & 8,37 \\
26 & 3,3 & 3,1 & 10,89 & 9,61 & 10,23 \\
27 & 3,2 & 2,7 & 10,24 & 7,29 & 8,64 \\
28 & 3,3 & 2,7 & 10,89 & 7,29 & 8,91 \\
29 & 3,1 & 2,9 & 9,61 & 8,41 & 8,99 \\
30 & 3,0 & 2,3 & 9,00 & 5,29 & 6,90 \\
\hline Total & $\mathbf{9 9 , 5}$ & $\mathbf{8 9 , 9}$ & $\mathbf{3 3 2 , 1 1}$ & $\mathbf{2 7 6 , 4 9}$ & $\mathbf{3 0 0 , 4 0}$ \\
\hline
\end{tabular}

Sumber: data primer di olah, 2015

Berdasarkan hasi1 pengolahan data di atas dapat diketahui besarnya jumlah variabel Produk baru (x) yaitu 99,5 dengan jumlah responden $(\mathrm{N})$ sebanyak 30 Orang, dan nilai variabel keputusan untuk membeli (y) yaitu 89,9 kemudian nilai Variabel produk baru (x) yang dikuadratkan yaitu sebesar 332,11, dan nilai variabel keputusan untuk membeli (y) yang dikuadratkan yaitu sebesar 276,49 dan nilai dari hasil perkalian Variabel Produk baru (x) dan Variabel keputusan untuk membeli (y) yaitu sebesar 300,400 .

Berdasarkan hasil perhitungan tersebut di atas maka dapat diketahui besarnya hubungan kedua variabel tersebut dengan memasukan ke dalam rumus product moment sebagai berikut :

$$
\begin{aligned}
\text { rxy } & =\frac{300,4-\frac{(99,5)(89,9)}{30}}{\sqrt{332,11-\frac{(99,5)^{2}}{30}} 276,49-\frac{(89,9)^{2}}{30}} \\
& =\frac{300,4-\frac{(99,5)(89,9)}{30}}{\sqrt{332,11-\frac{9.900,25}{30}} 276,49-\frac{8.082,01}{30}}
\end{aligned}
$$




$$
\begin{aligned}
& =\frac{300,4-298,17}{\sqrt{(332,11-330)(276,49-269,40)}} \\
& =\frac{2,24}{\sqrt{(2,11)(7,09)}} \\
& =\frac{2,24}{\sqrt{14,96}} \\
& =\frac{2,23167}{3,8678}=0,577
\end{aligned}
$$

Dengan mempergunakan ternyata lebih besar apabila rumus Product moment dari Person, dibandingkan dengan nilai korelasi maka dapat diketahui besarnya yang tercantum pada tabel nilai $\mathrm{r}$ koefisien antara variabel produk produk momen. Sehingga dapat baru dengan variabel keputusan disimpulkan bahwa koefesien untuk membeli rumah dikomplek korelasi kedua variabel yang diteliti perumahan Metro Indah milik PT.Doninda Menara Utama adalah signifikan atau positif.

Berdasarkan hasil koefesien Banjarmasin yaitu sebesar 0,577. korelasi kedua variabel tersebut, Sedangkan untuk mengetahui maka dapat diketahui bahwa apakah koefesien korelasi ini signifikan, maka perlu diuji dengan $\mathrm{r}$ tabel yang ada. Adapun $\mathrm{r}$ tabel untuk $\mathrm{N}$ sebesar 30 dengan taraf signifikan 5\% adalah 0,361. Jadi dengan demikian koefesien korelasi variabel Produk baru dengan variabel keputusan untuk membeli produk baru yang dihasilkan oleh PT.Donindo Menara Utama masih kurang memenuhi kriteria selera konsumen mengakibatkan keputusan untuk membeli menjadi menurun. Kedua kegiatan ini erat sekali hubungannya, sehingga dapat diperkirakan bahwa variabel 
produk baru menjadi faktor penentu terhadap tinggi rendahnya keputusan untuk membeli.

Selera konsumen tentang model atau desain bangunan yang berbeda-beda mengakibatkan model atau desain bangunan yang seragam kurang mendapat respon yang tinggi dari konsumen, demikian pula halnya jumlah kamar dan ukuran bangunan yang tidak mampu memenuhi kebutuhan konsumen yang mengakibatkan keputusan untuk membeli menjadi rendah, serta harga yang terlalu tinggi juga akan mengakibatkan melemahnya keputusan untuk membeli.

\section{KESIMPULAN DAN SARAN}

1) Karena besarnya koefesien korelasi antara variabel Produk baru dengan keputusan untuk membeli pada perumahan Metro Indah PT. Donindo Utama Banjarmasin adalah 0,577 ternyata lebih besar dari nilai $\quad r$ variabel 0,361,maka hipotesis yang diajukan dalam penelitian ini yang berbunyi Ada hubungan antara kegiatan pengembangan produk yaitu Produk baru dengan meningkatnya keputusan untuk membeli perumahan dikomplek Metro Indah yang dikelola oleh PT.Donindo Menara Utama Banjarmasin adalah diterima, sehingga Ho yang menyatakan tidak ada hubungan antara kegiatan pengembangan produk atau produk baru dengan meningkatnya keputusan untuk membeli adalah ditolak.

2) Hubungan kedua variabel yang diteliti bersifat simetris, karena kedua variabel ini berada pada posisi yang negatif. Disini dapat diperkirakan bahwa apabila ada terjadi perubahan pada satu variabel,maka perubahan itu akan diikuti searah oleh variabel yang berhubungan dengan variabel tertentu. 
3) Produk baru yang dihasilkan oleh PT.Donindo Menara Utama berupa perumahan yang dibangun dikomplek Metro Indah belum sepenuhnya memenuhi kriteria selera konsumen karena skornya menunjukan $63 \%$ dari seluruh responden yang diteliti berada pada posisi dibawah skor nilai rata-rata yaitu 3. Sehingga keputusan untuk membeli juga berada dibawah nilai rata-rata yaitu sejumlah $67 \%$ dari seluruh responden yang diteliti.

4) Mengingat eratnya hubungan antara produk baru yang dihasilkan dengan keputusan untuk membeli dari produk baru tersebut, lalu kemudian melihat kedua macam intensitas produk baru ternyata rendah atau kurang sepenuhnya memenuhi kriteria selera konsumen dan mempunyai nilai tidak jauh berbeda, maka dalam upaya meningkatkan keputusan untuk membeli dari produk baru tersebut hendaknya dilakukan secara berimbang, dan lebih terarah. Karena kurangnya perhatian terhadap arti pentingnya pemenuhan kriteria selera konsumen maka akan berakibat melemahnya keputusan untuk membeli dari produk baru yang ditawarkan tersebut. Sebaliknya bila ada upaya yang maksimal dilakukan oleh perusahaan untuk menyempurnakan produk baru yang dihasilkan dan disesuaikan dengan kriteria selera konsumen maka dengan sendirinya keputusan untuk membeli dari konsumenpun juga akan meningkat.

\section{Saran - saran}

1) Menghasilkan produk baru adalah merupakan tindak lanjut dari perwujudan strategi pengembangan produk yang mana sangat tepat dilakukan bilamana produk yang ada atau 
yang lama sudah dianggap tidak mampu lagi bersaing atau sudah ditinggalkan konsumennya.

2) Untuk memperkuat agar keputusan untuk membeli dari konsumen Perumahan yang dibangun oleh PT.Donindo Menara Utama lebih meningkat lagi maka hendaknya bangunan perumahan yang dibuat benarbenar mampu menyesuaikan dengan selera dan kemampuan konsumen terutama dalam hal model atau desain, ukuran luas maupun dari segi harganya.

\section{DAFTAR PUSTAKA}

Alex. S. Nitisomito, 1982, Marketing Ghatia Indonesia, Jakarta. 1990, Marketing, Edisi Kedua, Ghatia Indonesia, Jakarta.

Basu, S Wastha, 1996, Azas-Azas Marketing, Edisi Ketiga, Liberty Yogyakarta.

Joseph. P. Guiltinan dan Gordon. W. Pow, Toijom, Agus Maulana, 1987, Strategi dan Program
Manajemen Pemasaran, Edisi Kedua, Erlangga Jakarta.

Philip Kotler, 1988, Marketing Manajemen, Edisi Kelima, Erlangga Jakarta. 1988, Marketing Manajemen, Edisi Ketujuh, Erlangga Jakarta.

Soehardi Sigit, 1975, Marketing Praktis, Gadjah Mada University Pross Yogyakarta.

Surahmad, Winarto, 1970, Research Pengantar Metodologi Ilmiah, Edisi Keempat, Transito Bandung.

Tim Pembina Mata Kuliah Manajemen Pemasaran, Manajemen Pemasaran, Program Magister Manajemen Program Pasca Sarjana Universitas Wijaya Putra, Surabaya.

Winardi, 1981, Marketing Manajement, CV. Sinar Baru, Bandung. 